\title{
Morphology of Olfactory Sensilla and its Role in Host Plant Recognition by Neomegalotomus parvus (Westwood) (Heteroptera: Alydidae)
}

\author{
Maurício Ursi Ventura ${ }^{1 *}$ and Antônio Ricardo Panizzi ${ }^{2}$ \\ ${ }^{1}$ Departamento de Agronomia; Universidade Estadual de Londrina; C. P. 6001; 86051-970; Londrina - PR - Brasil. \\ ${ }^{2}$ Embrapa Soja; C. P. 231; 86001-970; Londrina - PR - Brasil
}

\begin{abstract}
The external morphology of the sensilla, including pores and permeable points on the cuticle of the antennae of adults of Neomegalotomus parvus (West.) (Heteroptera: Alydidae) was investigated with regard to their olfactory function. Behavioural evidence of olfaction, the importance of the different antennal segments in locating the host under still-air, and the responses of the insects to plants'scents and to pheromones in wind assays were also studied. With the scanning electronic microscope mechanoreceptor sensilla were found on the four segments of the antennae of $\mathrm{N}$. parvus. The density of the sensilla was greater on the $4^{\text {th }}$ segment. On the apical segment, sensilla with olfactory morphological traits were observed. Bugs with intact antennae located food more frequently and faster than those with blocked or amputated antennae. N. parvus preferred intact seeds to sealed seeds, but there was no preference when the last segment of the antenna was blocked. In wind tunnel, bugs were attracted to mature and green pods, and to hexanic extract of mature pods of pigeon pea, Cajanus cajan (L.) Millsp.; there was no response to panicles of rice, Oryza sativa $L$. or to the male pheromone.
\end{abstract}

Key words: Sensilla, host plant, behaviour, antenna

\section{INTRODUCTION}

Many studies on the chemical ecology of Heteroptera have been conducted on the responses of these insects to pheromones (references in Aldrich, 1988). However, despite some studies (e.g., Feir and Beck, 1963; Saxena, 1969; Pantle and Feir, 1976; Dickens et al., 1995; Sant'ana and Dickens, 1998; Sant'ana et al., 1999), few information are found in the literature about responses of heteropterans to host plant odors. Backus (1988) concluded that sensory systems and behaviours related to hemipteran feeding on plants have been poorly studied, and those differences among taxa were even less known.
Chemicals from plant species with which insect species are associated might elicit responses by those insects (Visser, 1986). Broad-headed bugs (Alydidae) are closely associated with leguminous plants (Schaefer, 1980; Schaefer and Mitchell, 1983), what may suggest that olfactory attraction of alydids to those plants is involved. Pods and seeds (mainly mature) of pigeon pea, Cajanus cajan (L.) Millsp., among several other leguminous host species, are suitable foods for nymphal development and adult reproduction of Neomegalotomus parvus (West.) (Heteroptera: Alydidae) (Panizzi, 1988; Ventura and Panizzi, 1997; Santos and Panizzi, 1998). Ventura and Panizzi (2004) showed that males of $N$. parvus

* Author for correspondence 
attract the same species in the field. This aggregation pheromone of $N$. parvus was identified and positive field responses were also obtained (W. Leal and A.R. Panizzi, unpublished). In this study, external morphology of the antennal sensilla of $N$. parvus was investigated, looking for pores and permeable points, as morphological evidence for an olfactory function of these sensilla. In addition, behavioural evidence of olfactory sense in $N$. parvus; the importance of the different segments of the antennae in locating the host under still-air conditions and in wind assays, and the responses of the insects to plants' odors and to the males aggregation pheromone were also studied.

\section{MATERIALS AND METHODS}

Insects. $N$. parvus insects were reared according to Ventura and Panizzi (1997). After emergence, the adults insects were separated and confined in acrylic boxes $(12.0 \times 12.0 \times 3.80 \mathrm{~cm})$ with pigeon pea pods and water for one week before the tests. In bioassays assessing responses to hosts (pods), insects were starved in the presence of water for $48 \mathrm{~h}$ before the tests were run.

Morphology of the Antennae Sensilla. To study the sensilla morphology, antennae of adults were dissected and mounted with double-sided tape on stubs, coated with gold, and observed in a scanning electronic microscope (Zeiss, DMS 940). The sensilla were observed in relation to external morphology and presence of pores. Antennae were treated with silver nitrate $(0.1 \%)$ for 30 minutes under dark condition for verification of permeable points on the cuticle (Peregrine, 1972).

Olfactory Responses. Males and females were grouped (except for pheromones responses) due to preliminary assays that revealed similar responses. To reduce movement, each insect was placed in the arena and confined within two plastic lids (2.5 $\mathrm{cm}$ diameter) for $15 \mathrm{~min}$. After this period the top lid was carefully removed and the insect was released. In the first test, one adult and one pigeon pea pod were placed at opposite corners in an acrylic box $(12.0 \times 12.0 \times 3.8 \mathrm{~cm})$ under still-air conditions. Insects were observed during $180 \mathrm{~min}$, and the time to locate the food, the distance traveled, and the percent of insects locating the food were recorded. The complete itinerary of each insect was drawn on squared paper. At the end of the experiment, the ranged distance was determined (cm) using a curvimeter (ASI, Switzerland). Treatments included adults with ablated antennae, with antennae blocked with shellac (Levin and Anfinogenova, 1981), and normal adults. Insects were maintained in the freezer $\left(-12^{\circ} \mathrm{C}\right)$ for $5 \mathrm{~min}$. to reduce their activity before manipulation for treatments. Each treatment was replicated four times, with 25 insects in each treatment.

A second still-air preference test was carried out in an arena and consisted of a Petri dish (12.0 x 1.5 $\mathrm{cm})$ with the bottom lined with filter paper for improve surface characteristics. Seeds of pigeon pea uncovered and sealed with Parafilm ${ }^{\circledR}$ were offered in paired-choice assays. Males and females with the $4^{\text {th }}$ segment of the antennae treated or without treating it with shellac were tested. Observations lasted $60 \mathrm{~min}$. and the food which was visited first was recorded.

A wind tunnel adapted from Prokopy et al. (1995) was used and consisted of a glass box (42.0 x 40.0 x $5.0 \mathrm{~cm}$ ) open at both ends and divided into 10 lanes. In one of the sides of each lane, the stimulus source was placed, isolated by a plastic mesh. The purified air (activated charcoal) was blown through the lanes $(0.39 \mathrm{~m} / \mathrm{s})$ with a fan. For each lane with stimulus source, another lane was set without stimulus source as control. The insects were placed on the opposite side of the stimulus, and observed until they reached the mesh (positive response) or moved away in the opposite direction (negative response). The time of response, positive or negative, was recorded. For each replication, 40 insects were used. The stimulus sources were: green pods of pigeon pea (4 replications); mature pods of pigeon pea (4); hexane extracts of mature pods of pigeon pea (4); hexane extracts of panicles of the non host plant rice (Oryza sativa L.) (4) ; and the synthetic pheromone from males (hexyl butyrate + hexyl valerate + hexyl hexanoate) (W. Leal and A.R. Panizzi, unpublished) [males (6) and females (6), used separately]. To obtain the extracts, pods were soaked in hexane ( $3 \mathrm{~g}$ pods $/ 10$ g extract) for $24 \mathrm{~h}$ (Prokopy et al., 1995).

Statistical Analysis. For the analysis of the study on preference for sealed and non-sealed seeds with Parafilm ${ }^{\circledR}$, using bugs with antennae blocked and unblocked, complete contingency tables were accomplished with two independent samples and 
two classes (Conover, 1981). Three hypotheses of nullity were tested: Ho1: No association among treatments and classes (responses); Ho2: No difference among the proportions of the treatments in each one of the classes; and Ho3: No difference among the proportions of the classes within each treatment. The same study was analyzed considering the proportions of insects with blocked, ablated or normal antennae that located the food (success); in this case, only the first two hypotheses were considered. For the variables time to locate the food and ranged distance, Duncan's multiple range test was used $(\mathrm{P} \leq 0.05)$. For the wind tunnel assay, Student's $t$ test was used $(\mathrm{P} \leq 0.05)$.

\section{RESULTS AND DISCUSSION}

\section{Morphology of the Antennae Sensilla}

Antennae of males and females of $N$. parvus have four segments; and the size and the distribution of sensilla were similar in both the sexes. Antenna of males was larger than that of the females and with the last segment longer. The density of sensilla increased from the first to the last segment. In the first three segments the surface of the antennae had irregular structures similar to scales (Fig. 1A). In all the segments, sensilla were bristle-like and their base fitt into a flexible socket (Fig. 1A), with a structure similar to a pore at the distal end (Fig. 1B). Silver nitrate did not accumulate in the sensilla tips. The insertion of the sensilla in a flexible socket is characteristic of mechanoreceptors (Frazier, 1985). In the heteropteran Oncopeltus fasciatus (Dallas) (Hem. Lygaeidae), two dendrites were verified in the sensilla with the flexible base, characterizing their mechanoreceptive function (Harbach and Larsen, 1976). Serrations were present on the surface of sensilla. In O. fasciatus and Lygaeus kalmii Stål (Hem. Lygaeidae), similar sensilla had serrations, which were also less abundant on the basal segments (Slifer and Sekhon, 1963; Harbach and Larsen, 1976).

Sensilla density was greater on the $4^{\text {th }}$ antennal segment than on the remaining ones (Fig. 1C). Sensilla with morphological characteristics for olfaction, similar to those showed by Frazier
(1985), were found on the last segment and were absent on the first three antennal segments of $N$. parvus. The grooved peg sensilla observed on the antennae were either inserted in a pit or lacked a flexible socket (Fig. 1D). These sensilla were smaller than most other sensilla of the antennae, particularly the one inserted in pits. Brézot et al., (1997) found pores in grooves of the antennal sensilla of Nezara viridula (L.) (Hem. Pentatomidae). Grooved pegs without flexible sockets were described in female hematophagous mosquitoes and responded to lactic and butyric acids (olfactory sensilla) (Bowen, 1995). Pores were also found in the base of the bristle sensilla without flexible sockets (Fig. 1C) being their extremity curved. Similar sensilla were also observed on the last segment of the antennae of $L$. kalmii, where they occur in the insertion of a nervous sheath of each hole (Slifer and Sekhon, 1963).

In the $4^{\text {th }}$ antennal segment of $N$. parvus, bristles with multiple pores, without flexible sockets, and with the extremity curved were also observed (Fig. 1F). Sensilla with multiple pores and without flexible sockets were also reported for $N$. viridula (Brézot et al., 1997). However, sensilla inserted in flexible sockets with striated surfaces and pores at the tip, small pores in the grooves, and multiple tips probably representing pores were described for Lygus lineolaris (Palisot de Beauvois) (Hem. Miridae) (Dickens et al., 1995).

Evidence that the last antennal segment is responsible for smell perception has also been reported for other species of heteropterans. In $O$. fasciatus, a considerably larger amount of nervous tissue was found in the fourth segment than in the first three segments (Andersen and Ball, 1959). The sensilla density in the last segment was also larger in Oxycarenus laetus Kirby (Hem. Lygaeidae), in comparison to the other segments (Raman, 1988). Sensilla with characteristics of olfaction were concentrated on the distal end of the terminal segment in Cimex lectularius $\mathrm{L}$. (Hem. Cemicidae) (Levinson et al., 1974). The highest density of sensilla occurred on the second segment of the flagellum in $N$. viridula (Brézot et al., 1997) and olfactory sensilla were located on the second and third segments in L. lineolaris (Dickens et al., 1995). 

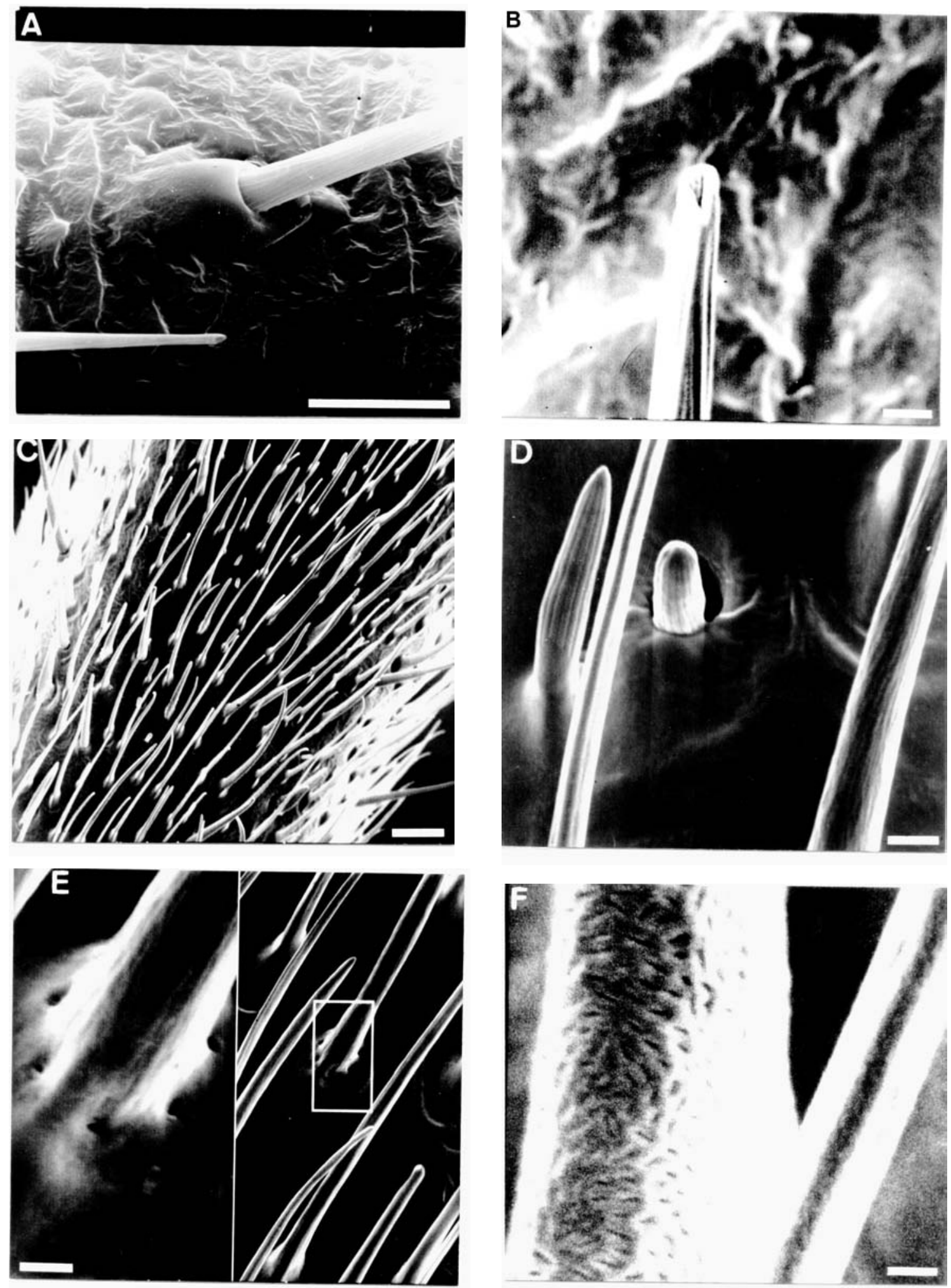

Figure 1 - Sensilla on the Neomegalotomus parvus antennae. A = sensilla in flexible socket $($ bar $=20 \mu \mathrm{m}) . \mathrm{B}=$ sensillum with a bevelled point $(\mathrm{bar}=2 \mu \mathrm{m}) . \mathrm{C}=$ apical segment with several types of sensilla $(\mathrm{bar}=20$ $\mu \mathrm{m}) . \mathrm{D}=$ grooved peg sensilla on apical segment $(\mathrm{bar}=2 \mu \mathrm{m}) . \mathrm{E}=$ bristle sensilla with holes in the base on apical segment $(\mathrm{bar}=20 \mu \mathrm{m}) . \mathrm{F}=$ multiple pores sensilla on terminal segment $(\mathrm{bar}=500 \mathrm{~nm})$. 
Comparing the antennae and sensillum of $N$. parvus observed in our study to that of another alydid, Riptortus clavatus (Thunberg) (IkedaKikue and Numata, 1991), several similarities could be established: difference on the size of the antennae in males and females; increased density of sensilla from the basal to the apical segments, with the greatest concentration on the terminal segment; nail-like projection on the base of the fourth segment; surface with structures similar to scales on the first three segments; sensilla in bristle form, with the base in a flexible socket; and grooved peg sensilla together with fine sensilla not inserted in flexible sockets at the distal segment. Detailed examination of the antennae of $R$. clavatus would probably reveal more similarities with N. parvus.

Backus (1988), considering the hypothesis of Chapman (1982) that a greater number of chemoreceptors allowed a increased possibility of perception of the chemical atmosphere, pointed out that the high number of sensilla found on the antennal flagellum of Heteroptera could be used to detect olfactory cues during orientation at a long distance from the host plant. Also, probably the volatiles emanated from the surface of plants, and the interaction of chemicals and texture in contact with cuticle during the exploration and antennation of the plant surface, were detected by these insects.

\section{Olfactory Responses}

In the first still-air assay, the percentage of intact insects that located the food (91\%) was significantly higher than that of insects which had the antennae blocked with shellac or ablated (Table 1). Insects with intact antennae located the food faster than those with ablated antennae or those which had the antennae blocked with shellac (145.1 min.). These results showed the importance of antennal sensilla for locating the host plant. In relation to the distance traveled to reach the food, no significant differences were found among the treatments; suggesting that this was not a good parameter for verifying olfactory responses. The relative small size of the arena might have contributed to the absence of significant differences among treatments. Further studies could verify these hypothesis.

Table 1 - Percentage of Neomegalotomus parvus (Het.: Alydidae) adults that located the food, time, to locate the food, and distance traveled to reach the food (pigeon pea pod) in different treatments to their antennae.

\begin{tabular}{l|c|c|c}
\hline Treatments & $\begin{array}{c}\text { \% insects } \\
\text { found pod }\end{array}$ & Time (min.) & $\begin{array}{c}\text { Traveled } \\
\text { distance }(\mathbf{c m})^{\mathbf{2}}\end{array}$ \\
\hline $\begin{array}{c}\text { Antennae } \\
\text { with shellac } \\
\text { Antennae } \\
\text { ablated }\end{array}$ & $35 \mathrm{~b}$ & $145.1 \pm 7.6 \mathrm{a}$ & $19.4 \pm 5.3 \mathrm{a}$ \\
Normal \\
Antennae
\end{tabular}

Males and females visited preferentially nonsealed seeds, indicating host detection by smell. However, males and females with the last segment of the antennae blocked did not detect seeds by smell (Table 2). These results corroborated the morphological evidence that the last segment of antenna might be suggested as the "olfactory segment." The olfactory results also confirmed those from the previous still-air experiment. Numata et al. (1986) found that the removal of the apical segment of the antennae prevented the initiation of courtship behaviour in the alydid $R$. clavatus. Flagellum of the C. lectularius antenna had a higher capacity to perceive scents of the host than in the other segments (Levin and Anfinogenova 1981). The ablation of the last segment of the antenna in this specie also prevented the reaction to certain concentrations of the alarm pheromone, and stopped the aggregation behaviour (Levinson et al., 1974). In antenna ablation experiments with Podisus maculiventris (Say) (Het.: Pentatomidae), the sensilla response to plant volatile were found mainly on the terminal antennal segment (Sant'ana et al., 1999). 
In the wind-tunnel tests, no positive responses were found considering the time to reach the mesh with the stimulus source. However, for green and dry pods, and hexanic extract positive responses were found for percent insects reached the screen (source of stimulus) (Table 3 ). In the treatments with panicles of the non host rice and pheromones, for males and females, no significant differences were found. Positive responses of $N$. parvus to pheromones were obtained in the field (W. Leal and A.R. Panizzi, unpublished). Probably, the wind tunnel used in this assay did not provide the conditions for positive responses or these results reflected insect behavior in which feeding was selected during walking and pheromones detected during flying.
In relation to the negative responses, the treatments did not differ from the control $(\mathrm{P} \leq$ 0.05) (Table 3).

The responses obtained in this study corroborated other studies with olfactory perception that, although scarce in Heteroptera (Backus, 1988), indicated its importance in host plant selection. In general, these studies were also conducted over small distances, reflecting the behaviour of the insect on the surface of the plant, rather than that before reaching it. In all bioassays, the insects walked and dabbed the surface with the labial tip simultaneously, probably combining olfactory and gustatory senses.

Table 2 - Preference of males and females of Neomegalotomus parvus (Het.: Alydidae) for sealed and non-sealed seeds of pigeon pea sealed or not, with the last segment of the antennae blocked or not $(\mathrm{n}=100)$.

\begin{tabular}{llll}
\hline \multicolumn{2}{l}{ Treatment } & Sealed (\%) & Not sealed (\%) \\
\hline \multirow{2}{*}{ Males } & Antennae blocked & $0.59 \mathrm{Aa}$ & $0.41 \mathrm{aB}$ \\
& & & \\
& Antennae unblocked & $0.21 \mathrm{Bb}$ & $0.79 \mathrm{aA}$ \\
\multirow{2}{*}{ Females } & Antennae blocked & $0.51 \mathrm{Aa}$ & $0.49 \mathrm{aB}$ \\
& & & \\
& Antennae unblocked & $0.05 \mathrm{Bb}$ & $0.95 \mathrm{aA}$ \\
\hline
\end{tabular}

Means with the same lower case letter in the line, and upper case letter in the column, do not differ significantly (P < $0.05)$ (complete study of contingency tables).

Table 3 - Percentage of Neomegalotomus parvus (Heteroptera: Alydidae) ( \pm SEM) adults showing positive and negative responses to green pods, dry pods, hexanic extracts of dry pods of pigeon pea, panicles of rice (data of females and males combined), and male pheromone (males and females separately), in wind-tunnel with and without stimulus source.

\begin{tabular}{lll}
\hline Treatment & With & Without \\
& & \\
\hline POSITIVE RESPONSES & $30.0(6.0) \mathrm{a}$ & \\
Green pods & $53.0(15.0) \mathrm{a}$ & $15.0(3.0) \mathrm{b}$ \\
Dry pods & $28.0(10.0) \mathrm{a}$ & $14.0(5.0) \mathrm{b}$ \\
Hexanic extract & $15.0(5.0) \mathrm{a}$ & $6.0(4.0) \mathrm{b}$ \\
Panicles of rice & $17.0(4.0) \mathrm{a}$ & $16.0(10.0) \mathrm{a}$ \\
Pheromone (males) & $18.0(10.0) \mathrm{a}$ & $12.0(5.0) \mathrm{a}$ \\
Pheromone (females) & & $15.0(3.0) \mathrm{a}$ \\
NEGATIVE RESPONSES & $8.0(3.0) \mathrm{a}$ & $7.0(4.0) \mathrm{a}$ \\
Green pods & $18.0(4.0) \mathrm{a}$ & $18.0(10.0) \mathrm{a}$ \\
Dry pods & $12.0(6.0) \mathrm{a}$ & $16.0(10.0) \mathrm{a}$ \\
Hexanic extract & $20.0(8.0) \mathrm{a}$ & $12.0(10.0) \mathrm{a}$ \\
Panicles of rice & $12.0(8.0) \mathrm{a}$ & $18.0(6.0) \mathrm{a}$ \\
Pheromone (males) & $12.0(6.0) \mathrm{a}$ & $12.0(6.0) \mathrm{a}$ \\
Pheromone (females) &
\end{tabular}

Mean $( \pm$ SEM) with the same letter in the line do not differ significantly $(\mathrm{P}<0.05)$ using Student's $t$ test. 
Other evidences of host plant olfactory recognition included the receptors to volatiles of the host plant Asclepias syriaca L. that were found in $O$. fasciatus (Pantle and Feir, 1976). This insect had a reduced ability to locate seeds of $A$. syriaca after the sensorial structures of their antennae were blocked (Feir and Beck, 1963).

Dysdercus koenigii (F.) (Het.: Pyrrhocoridae) was also attracted to host plant scents, green leaves of cotton (Gossypium hirsutum L.), probably by the presence of essential oils (Saxena, 1969). In the same study, the insects were more attracted to the seeds of cotton and okra, Abelmoschus esculentus Moench., than those of other hosts. In Magicicada cassini (Fisher) (Hom.: Cicadidae), sensilla sensitive to host plant odors were found in the antennae (Klein et al., 1988). In Aphis glycines Matsumura (Hom.: Aphydidae), responses to terpene derivatives (alcohols, aldehydes, and esters), green odors of leaves, and aromatic compounds (Yongjun et al., 1995) were obtained. Recent progress in the knowledge of the chemical composition of volatile from plants, especially of legumes (Liu et al., 1989), and their isolation, together with electroantennogram studies, might elucidate in greater detail how olfactory stimulation in $N$. parvus occurred. Dickens et al. (1995) characterized positive responses of $L$. lineolaris to 1-hexanol, the chemical of the "green" odor. Similarly, $P$. maculiventris and $P$. nigrispinus (Dallas) were found to be sensitive to plant volatile (Sant'ana and Dickens, 1998; Sant'ana et al., 1999).

In conclusion, mechanoreceptor sensilla were found on the four segments of the antennae of $N$. parvus, and were in highest numbers on the $4^{\text {th }}$ segment. Bugs with intact antennae located food more frequently and faster than those with blocked or amputated antennae; They detected intact seeds and sealed seeds, but no detection ocurred when the last segment of the antenna was blocked. In wind tunnel, bugs were attracted to mature and green pods, and to hexanic extract of mature pods of pigeon pea; but there was no response to panicles of rice and to the pheromone extracted from males. These results indicated that $N$. parvus did perceive the scents of pods of closely related leguminous plants.

\section{ACKNOWLEDGMENTS}

We thank I.C.B. Fonseca (State University of Londrina) for statistical assistance, E.W. Kitajima (NAP/NEPA, ESALQ/USP) for electronic microscopy assistance and facilities, and P.M.O.J. Neves for photographs assistance.

\section{RESUMO}

A morfologia externa dos sensilos de adultos de Neomegalotomus parvus (Westw.) (Het.: Alydidae), incluindo poros e pontos permeáveis na cutícula, foi estudada em microscópio eletrônico de varredura, em relação à função olfativa. A evidência comportamental do olfato e a importância dos diferentes segmentos antenais na localização do hospedeiro, em condições de ausência de movimentação do ar, foram também estudados. Sensilos mecanoreceptores foram observados nos quatro segmentos da antena de $N$. parvus, sendo no entanto, a densidade maior no quarto segmento. Nos segmentos apicais, foram observados sensilos com características morfológicas olfativas. Percevejos com antenas intactas localizaram o alimento com mais frequiência e rapidez do que aqueles com antenas bloqueadas ou amputadas. Adultos de N. parvus preferiram sementes intactas do que aquelas vedadas com Parafilm®, mas não apresentaram preferência quando o último segmento da antena foi bloqueado. Em túnel de vento, os percevejos foram atraídos para sementes e vagens maduras, e para extrato hexânico de vagens maduras de guandu, Cajanus cajan (L.) Millsp.; não houve resposta para panículas de arroz, Oryza sativa L. (planta não hospedeira) ou para feromônio extraído de machos.

\section{REFERENCES}

Aldrich, J. R. (1988), Chemical ecology of the Heteroptera. Annu. Rev. Entomol., 33, 211-38.

Andersen, L. W. and Ball, H. J. (1959), Antennal hygroreceptors of the milkweed bug, Oncopeltus fasciatus (Dallas) (Hemiptera, Lygaeidae). Ann. Entomol. Soc. Am., 52, 279-284.

Backus, E. A. (1988), Sensory systems and behaviours which mediate hemipteran plant-feeding: a taxonomic overview. J. Insect Physiol., 34, 151-165. 
Bowen, M. F. (1995), Sensilla basiconica (grooved pegs) on the antennae of female mosquitoes: electrophysiology and morphology. Entomol. Exp. Appl., 77, 233-238.

Brézot, P.; Tauban, D. and Renou, M. (1997), Sense organs on the antennal flagellum of the green stink bug, Nezara viridula (L.) (Heteroptera: Pentatomidae): sensillum types and numerical growth during the post-embryonic development. Int. J. Insect Morphol. Embryol., 25, 427-441.

Chapman, R. F. (1982), Chemoreception: the significance of receptor numbers. Adv. Insect Physiol., 16, 247-336.

Conover, W. J. (1981), Practical Nonparametric Statistics. $2^{\text {nd }}$ ed. New York : Wiley.

Dickens, J. C.; Callahan, F. E.; Wergin, W. P. and Erbe, E. F. (1995), Olfaction in a hemimetabolous insect: antennal-specific protein in adult Lygus lineolaris (Heteroptera: Miridae). J. Insect Physiol., 41, 857-867.

Feir, D. and Beck, S. D. (1963), Feeding behavior of the large milkweed bug, Oncopeltus fasciatus. Ann. Entomol. Soc. Am., 56, 224-229.

Frazier, J. L. (1985), Nervous System: Sensory System. In: Blum, M. S. (Ed.). Fundamentals of Insect Physiology. New York : J. Wiley and Sons. pp. 287-356.

Harbach, R. E. and Larsen, J. R. (1976), Ultrastructure of sensilla on the distal antennal segment of adult Oncopeltus fasciatus (Dallas) (Hemiptera: Lygaeidae). Int. J. Insect Morphol. Embryol., 5, 23-33.

Ikeda-Kikue, K. and Numata, H. (1991), Compensatory regeneration of antennae after removal of the distal segment in Riptortus clavatus (Thunberg) (Heteroptera: Alydidae). Int. J. Insect Morphol. Embryol., 20, 41-49.

Klein, U.; Bock, C.; Kafka, W.A. and Moore, T.E. (1988), Antennal sensilla of Magicicada cassini (Fisher) (Homoptera: Cicadidae): fine structure and electrophysiological evidence for olfaction. Int. J. Insect Morphol. Embryol., 17, 153-167.

Levin, N. A. and Anfinogenova, V. G. (1981). Olfactometric Evaluation of the Chemoreceptor Capacity of the Antennal Segments of Insects for Orientation by Odor of the Nutritive Substrata. In: Pristavko, V. P. (Ed.): Insect Behavior as a Basis for Developing Control Measures Against Pests of Field Crops and Forests. New Delhi : Oxamain Press. pp. 95-100.

Levinson, H. Z.; Levinson, A. R.; Müller, B. and Steinbrecht, R. A. (1974), Structure of sensilla, olfactory perception, and behaviour of the bedbug, Cimex lectularius, in response to its alarm pheromone. J. Insect Physiol., 20, 1231-1248.

Liu, S.; Norris, D. M. and Lyne, P. (1989), Volatiles from the foliage of soybean, Glycine max, and lima bean, Phaseolus lunatus: their behavioral effects on the insects Trichoplusia ni and Epilachna varivestis. J. Agric. Food Chem., 37, 496-501.
Numata, H.; Matsui, N. and Hikada, T. (1986), Mating behavior of the bean bug, Riptortus clavatus Thunberg (Heteroptera: Coreidae): Behavioral sequence and the role of olfaction. Appl. Ent. Zool., 21, 119-125.

Panizzi, A. R. (1988), Biology of Megalotomus parvus (Hemiptera: Alydidae) on selected leguminous food plants. Insect Sci. Applic., 9, 279-285.

Pantle, C. and Feir, D. (1976), Olfactory responses to milkweed seed estracts in the milkweed bug. J. Insect Physiol., 22, 285-289.

Peregrine, D. J. (1972), Fine structure of sensilla baxiconica on the labium of the cotton stainer, Dysdercus fasciatus (Signoret) (Heteroptera: Pyrrhocoridae). Int. J. Insect Morphol. Embryol., 1, 241-251.

Prokopy, R. J.; Cooley, S. S. and Phelan, P. L. (1995), Bioassay approaches to assessing behavioral responses of plum curculio adults (Coleoptera: Curculionidae) to host fruit odor. J. Chem. Ecol., 21, 1073-1084.

Raman, K. (1988), Behavioural attributes of Oxycarenus laetus Kirby towards different malvaceous seeds. Phytophaga, 2, 57-71.

Sant'ana, J. and Dickens, J. C. (1998), Comparative electrophysiological studies of olfaction in predaceous bugs, Podisus maculiventris and $P$. nigrispinus. J. Chem. Ecol., 24, 965-984.

Sant'ana, J.; Silva, R. F. P. and Dickens, J. C. (1999), Olfactory reception of nonspecific aggregation pheromone and plant odors by nymphs of the predator, Podisus maculiventris. J. Chem. Ecol., 25, 1813-1826.

Santos, C. H. and Panizzi, A. R. (1998), Nymphal and adult performance of Neomegalotomus parvus (Hemiptera: Alydidae) on wild and cultivated legumes. Ann. Entomol. Soc. Am., 91, 445-451.

Saxena, K. N. (1969), Patterns of insect-plant relationships determining susceptibility or resistance of different plants to an insect. Entomol. Exp. Appl., 12, 751-766.

Schaefer, C. W. (1980), The host plants of the Alydidae, with a note on heterotypic feeding aggregations (Hemiptera: Coreoidae: Alydidae). J. Kansas Entomol. Soc., 53, 115-122.

Schaefer, C.W. and Mitchel, P.L. (1983), Food plants of the Coreoidea (Hemiptera: Heteroptera). Ann. Entomol. Soc. Am., 76, 591-615.

Slifer, E. H. and Sekhon, S. S. (1963), Sense organs on the antennal flagellum of the small milkweed bug, Lygaeus kalmii Stal (Hemiptera, Lygaeidae). J. Insect Morphol., 112, 165-193.

Ventura, M. U. and Panizzi, A. R. (1997), Megalotomus parvus West. (Hemiptera: Alydidae): Inseto adequado para experimentação e didática entomológica. An. Soc. Entomol. Brasil, 26, 579-581. 
Ventura, M. U. and Panizzi, A. R. (2004), Responses of Neomegalotomus parvus (Hemiptera: Alydidae) to color and male-lured traps. Braz. Arch. Biol. Tech. (in press).

Visser, J. H. (1986), Host odor perception in phytophagous insects. Annu. Rev. Entomol., 31, 121-144.

Yogjun, D.; Fusnhun, Y. and Jue, T. (1995), Structure and function of olfactory sensilla on the antennae of soybean aphids, Aphis glycines. Acta Entomol. Sinica, 38, 1-7. 